Article

\title{
Managing Sustainability Aspects in Renovation Processes: Interview Study and Outline of a Process Model
}

\author{
Stefan Olsson ${ }^{1, *}$, Tove Malmqvist ${ }^{1}$ and Mauritz Glaumann ${ }^{2}$ \\ 1 Division of Environmental Strategies Research, KTH Royal Institute of Technology, \\ SE-100 44 Stockholm, Sweden; E-Mail: tove.malmqvist@abe.kth.se \\ 2 Faculty of Engineering and Sustainable Development, University of Gävle, SE-801 76 Gävle, \\ Sweden; E-Mail: mauritz.glaumann@hig.se \\ * Author to whom correspondence should be addressed; E-Mail: stefan.olsson@abe.kth.se; \\ Tel.: +46-8-5888-8118; Fax: +46-8-790-8580.
}

Academic Editor: Sangkyun Kim

Received: 6 March 2015 / Accepted: 15 May 2015 / Published: 25 May 2015

\begin{abstract}
In many European countries, there are building stocks in need of extensive renovation. This constitutes an important opportunity to perform energy-saving measures and improve indoor environmental quality aiming at a more sustainable built environment. In this paper, we report results from an interview study with the aim of obtaining an in-depth understanding of renovation processes and how sustainability aspects are handled by various Swedish property owners. Examples of important barriers revealed in the interviews are insufficient inspection of existing buildings, absence of both overarching and detailed sustainability targets and guidelines, and lack of knowledge about sustainability aspects. Based on the interview study, conclusions are drawn for the further development of a process model which aims at systematize integration and effectively address energy, environmental, and indoor environmental quality aspects throughout a renovation process; we refer to this as sustainable renovation. Some key starting points for the process model are to suggest routines, provide checklists and tools, and offer guidance for formulating sustainability targets. However, the interviews show that in order to reach a more sustainable built environment, there is a need for government subsidies, other incentives or new business models that value environmental aspects higher.
\end{abstract}

Keywords: sustainability management; renovation; housing; process; interviews; barriers 


\section{Introduction}

Building stocks throughout the European Union (EU) are currently facing a vast renovation need. How this renovation need will be handled plays an important role for the ability to reduce society's future energy demands, climate change mitigation, and enhancement of indoor environmental quality for numerous people. New construction accounts for only about $1 \%$ annual addition to the total gross floor area in the EU [1]. The major potential for reducing energy demand therefore lies in upgrading the existing building stock.

How to increase energy efficiency and reduce emissions of greenhouse gases are issues of high priority for the European Commission [2]. This has been expressed in the Energy Efficiency Directive 2012/27/EU [3], which, among other things, stipulates that member states should develop targets for energy efficiency and formulate a long-term strategy (beyond year 2020) for renovation of buildings. In line with these overarching targets, the Swedish Parliament has developed 16 Environmental Quality Objectives (EQOs) [4]. Each EQO consists of several indicators and various milestones; the EQOs originate in 1998 [5]. In the EQO of "Good Built Environment" (indicators such as energy efficiency, greenhouse gas emissions, noise, damp problems), one example of such a milestone is to reduce total energy demand per unit heated area in the built environment by $20 \%$ by year 2020 . The ambition is a reduction of 50\% in year 2050 compared with baseline year of 1995 [6-8].

The total number of dwellings in the Swedish building stock is about 4.5 million units according to the database of Statistics Sweden [9]. In many places in Sweden, there are large residential areas that were built during the 1960s and 1970s. Dwellings in multi-family buildings from the period 1961-1975, which in Sweden is referred to as the "record years" [10], account for roughly 20\% of the building stock and thus also represent a large part of the built environment in the country. These buildings are now 40-50 years old and in many cases in need of extensive renovation measures, such as replacement of plumbing equipment, ventilation, windows, and roof. The situation is similar in many European countries [1,11]. This constitutes an important opportunity to adopt energy-saving measures and improve indoor environmental quality when renovating these buildings, not just restoring original functions [12-15]. To incorporate the full potential of energy-saving measures, there might also be a need of behavioral change among residents, which is why it is important to have a participatory process when renovating [16].

In contrast to production of new buildings, far-reaching renovation focusing on reducing energy demand along with enhanced indoor environment are still seen mainly as pilot cases; according to Liu and Thoresson (2013) [17], these kinds of projects are performed on a small scale in Sweden. Barriers to implementation of renovation processes towards more sustainable buildings have been investigated for example by Thuvander et al., 2012 [12], Cattano et al., 2013 [18], and Häkkinen and Belloni (2011) [19]. In addition to the fear of high investment costs and problems with profitability, key barriers identified in these studies include lack of knowledge about sustainability aspects, lack of simplified evaluation tools (for decision making), insufficient knowledge of building stocks, and lack of coordination between energy-saving and other measures. Consequently, very few property owners manage to address sustainability aspects throughout a renovation project in a satisfactory manner. Finding ways to overcome similar barriers is crucial and requires identification and development of sustainability management procedures. 
In this paper, we report the results of an interview study with the purpose of obtaining an in-depth understanding of current renovation processes and how sustainability aspects are handled by various Swedish property owner organizations. More specifically, the research questions were: how do Swedish property owners address sustainability aspects in their current renovation processes and what barriers do they encounter in relation to that?

From the interviews, conclusions are drawn for the further development of a process model. The process model is supposed to be a generic gross process model that helps systematize integration and effective handling of sustainability aspects throughout a renovation process. The aim of the model is to emphasize important aspects such as energy, environmental, and indoor environmental quality aspects but also to encourage more challenging sustainability objectives for renovation projects. To integrate systematic treatment of sustainability aspects into the regular renovation process, or rather to convert the regular renovation process into a process for sustainable renovation, requires collaboration with important stakeholders in the building industry.

The notion sustainable renovation has emerged within this context as a means to handle renovation needs and simultaneously contribute to the fulfillment of central societal targets. In this paper, we refer to sustainable renovation as the handling of energy, environmental, and indoor environmental quality aspects throughout a renovation process. However, the interpretation of sustainable renovation is to a high degree varying and toward the end of the paper, we will get back to this notion.

\section{Methodology}

The research method used for this study consisted of qualitative interviews conducted in a semi-structured manner. The qualitative interviews were conducted in order to gain an overview, as well as more in-depth understanding of the current incorporation of sustainability aspects in renovation projects of multifamily buildings. The interviews included six Swedish property owner organizations (A-F in Table 1) and were to a high extent open-ended and conducted in accordance with the stepwise methodology described by Kvale and Brinkmann [20].

The six organizations in this study were selected in order to obtain a representative sample of the housing industry. The organizations represent three important categories of Swedish residential property owners: small and medium-sized private companies, large publicly owned companies and housing cooperatives. However, our focus is on organizations owning rental apartments. In total, the participating organizations own about 57,700 rental apartments, which correspond to approximately 3.5 million square meters of dwellings. Additionally, two of the organizations also represent a vast number (approximately 6400) of housing cooperatives of various sizes throughout Sweden with facility management responsibilities. A housing cooperative is an organization in which each apartment owner is a member; all members cooperatively share economic responsibility for the real estate and buildings. Thus, these six organizations represent a relatively large percentage of the total number of dwellings in Swedish multi-family buildings. The participating organizations also represent property owners in both the non-growth and growth markets of Sweden.

Interviews were conducted during 2013 with each organization's representative with environmental expertise or responsibility for environmental issues. In two of the organizations ( $\mathrm{D}$ and $\mathrm{E}$ in Table 1), an additional interview was conducted with a respondent who was experienced in the operating side of 
renovation projects. Profiles of interviewees and the organization they represent are shown in Table 1. A total of eight interviews were conducted, recorded and transcribed, each lasting for approximately two hours.

Table 1. Characterization of organizations and respondents in the interview study.

\begin{tabular}{|c|c|c|c|}
\hline Organization & $\begin{array}{l}\text { Characterization of } \\
\text { organization }\end{array}$ & $\begin{array}{l}\text { Role of the } \\
\text { respondent(s) }\end{array}$ & $\begin{array}{l}\text { Work area/main responsibilities of } \\
\text { respondent(s) }\end{array}$ \\
\hline A & $\begin{array}{l}\text { Large, publicly } \\
\text { owned, operating on } \\
\text { a growth market. }\end{array}$ & $\begin{array}{l}\text { Consultant } \\
\text { representing the } \\
\text { Construction and } \\
\text { Engineering Manager }\end{array}$ & $\begin{array}{l}\text { Construction manager on a consulting basis. } \\
\text { Responsible for coordination, management and } \\
\text { monitoring of a project. }\end{array}$ \\
\hline
\end{tabular}

\begin{tabular}{|c|c|c|c|}
\hline B & $\begin{array}{l}\text { Very small, privately } \\
\text { owned, operating on } \\
\text { a non-growth market. }\end{array}$ & Owner & $\begin{array}{l}\text { The owner is active in the company and has } \\
\text { responsibility for daily work and all projects, } \\
\text { only one person (an administrator) employed by } \\
\text { the company. }\end{array}$ \\
\hline $\mathrm{C}$ & $\begin{array}{l}\text { Small, privately } \\
\text { owned, operating on } \\
\text { a non-growth market. }\end{array}$ & Co-owner & $\begin{array}{l}\text { Not active in daily work, contributes on a } \\
\text { consulting basis regarding property management } \\
\text { issues. Only one person (a property manager) } \\
\text { employed by the company. }\end{array}$ \\
\hline & I aro memher & $\begin{array}{l}\text { Environmental and } \\
\text { Sustainability } \\
\text { Manager }\end{array}$ & $\begin{array}{l}\text { Supports the organization with expertise } \\
\text { regarding environmental and sustainability } \\
\text { aspects. Pursues lobbying and advocacy in the } \\
\text { construction and housing industry. }\end{array}$ \\
\hline $\mathrm{D}$ & $\begin{array}{l}\text { owned cooperative } \\
\text { organization } \\
\text { (private), operates all } \\
\text { over Sweden. }\end{array}$ & $\begin{array}{l}\text { Property Manager } \\
+ \\
\text { Project Manager }\end{array}$ & $\begin{array}{l}\text { Responsible for the development of the real estate } \\
\text { portfolio and the company's long-term planning } \\
\text { and strategy in the Stockholm region. } \\
\text { Responsible for all major renovation projects } \\
\text { from early stages to follow-up in the Stockholm } \\
\text { region. In charge of the project managers and } \\
\text { reports to the Property Manager. }\end{array}$ \\
\hline \multirow{2}{*}{$\mathrm{E}$} & \multirow{2}{*}{$\begin{array}{l}\text { Medium-sized, } \\
\text { member-owned } \\
\text { cooperative } \\
\text { organization } \\
\text { (private), operates all } \\
\text { over Sweden. }\end{array}$} & $\begin{array}{l}\text { Environmental and } \\
\text { Quality Coordinator }\end{array}$ & $\begin{array}{l}\text { Supports the organization and implementation of } \\
\text { internal routines regarding environmental rating } \\
\text { tools and related issues. }\end{array}$ \\
\hline & & $\begin{array}{l}\text { Project Manager of } \\
\text { Redevelopment }\end{array}$ & $\begin{array}{l}\text { Responsible for some major renovation projects } \\
\text { from early stages to follow-up in central Sweden. }\end{array}$ \\
\hline $\mathrm{F}$ & $\begin{array}{l}\text { Large, publicly } \\
\text { owned, operating on } \\
\text { a growth market. }\end{array}$ & $\begin{array}{l}\text { Environmental } \\
\text { Coordinator } \\
\qquad+ \\
\text { Project Manager }\end{array}$ & $\begin{array}{l}\text { Supports the organization with expertise regarding } \\
\text { environmental aspects. Together with the Project } \\
\text { Manager and Construction Manager, responsible } \\
\text { for the company's long-term planning and strategy. } \\
\text { Together with the Environmental Coordinator and } \\
\text { Construction Manager, responsible for the } \\
\text { company's long-term planning and strategy. } \\
\text { In charge of the company's project managers. }\end{array}$ \\
\hline
\end{tabular}


Interview questions were based on our previous experience and studies that identify barriers to sustainable renovation to be a lack of simplified methods, procedures and checklists to address sustainability aspects in renovation projects $[12,18,19]$. Seventy interview questions were developed and assigned to various categories. The categories were intended to represent various stages of a typical construction process but also involved questions regarding economic aspects and information and communication technology solutions. Most questions were open-ended since our purpose was to gain an understanding of problems and possibilities in current renovation processes among the participating organizations. The resulting presentation of the interviews is based on common themes occurring in the analysis of the answers. When there were clear differences between answers from different types of organizations, this has been stated in each subchapter in Section 3 and in the concluding discussion (Section 4).

All interview questions can be found as supplementary information to this paper. All questions were sent out in advance so that the respondents could prepare. Many of the questions provided opportunities for deliberation between the respondents and the researchers during the interviews. Not all respondents were able to answer all questions but could instead reflect on what they would want to do in certain situations, thus providing useful input for the development of the process model.

\section{Results and Analysis}

Presentation of the interviews is broken down into six sections, starting with economic aspects prior to a project and continuing all the way through to follow-up (Sections 3.1-3.6 below) and how some sustainability aspects are handled in the various stages.

\subsection{Economic Aspects of Decision Making}

Owners of rental properties must receive consent from each tenant before performing measures in the various apartments and the consent of at least half of them before performing measures in public spaces in the building that will lead to increased rent [21]. Increases in rent are based on the utility value principle. The utility value should reflect the value of the apartment from the tenant's point of view. Utility value is affected by things like the size, what floor, and the overall standard of the apartment and building [22]. However, ordinary maintenance should not lead to an increase in rent.

The interviews indicate that no or very little funding is usually set aside for renovation purposes, maintenance or modernization, regardless of whether it is a publicly or a privately owned organization. The lack of funding is mainly due to an agreement between the Swedish Property Federation and the Swedish Union of Tenants for tax reasons. Thus, each renovation project has to be funded by increased rents and reduced operational costs, which leads to attempts to keep costs down. When it comes to housing cooperatives, the picture is somewhat different: financial opportunities are often better since a housing cooperative usually arranges its finances in line with a maintenance plan and does not follow the kind of agreement mentioned above.

Another economic aspect that influences decisions about measures to be taken is expected return on investments. The higher the rate of return, the fewer measures will be profitable. Five out of the six interviewed organizations have an overall required rate of return and one has a specific rate of return for each individual property. The rate of return among the participating organizations is typically 
$4 \%-7 \%$. When estimating profitability, most of the interviewees said that their organization used some kind of Life Cycle Cost (LCC) approach, but it greatly depended on the project manager, and some of them used only simple payback time estimates. One problem that was identified was the lack of overarching guidelines for economic evaluation and the numbers to use. Even within the same organization, different numbers for the same parameter (e.g., annual increase in energy prices, useful life of products) are used when estimating profitability. Often the project manager determines what parameters to use, and this leads to completely different evaluations of the same measure during similar projects.

Except for the problem of funding, possibilities or problems identified in this section include:

- Large differences within an organization when evaluating different potential renovation measures, both in economic and technical terms.

- LCC approaches could be used more frequently when estimating profitability.

- Lack of overarching guidelines for input data to economic evaluation.

\subsection{Property Management}

Regarding maintenance plans, three organizations use more or less comprehensive maintenance plans for their properties, but none of them includes sustainability objectives. The two smaller organizations do not have maintenance plans. However, the interviews revealed that due to them being small, the facility manager has good tacit knowledge about the status of each building.

Three out of the six participating organizations, all of which are large, have overarching sustainability objectives specifically related to renovation. The remaining three organizations said that they did not have any overarching sustainability targets. The four larger organizations all have Environmental Management Systems (EMS) certified according to the ISO 14001 standard. But the picture varies for overarching sustainability targets. Two out of the three organizations that have overarching sustainability objectives said that their goal was to reduce operational energy demand by $20 \%$ when performing a major renovation project; the target is based on the Swedish EQO for year 2020 [8]. The last organization said that their goal was to reduce operational energy demand by 50\% when performing a major renovation project.

Monitoring and follow-up of the use of energy and domestic tap water in the management process is also an important starting point for formulating adequate sustainability targets and selecting measures in a renovation process. Five out of the six organizations monitor energy use in one way or another. However, analysis of the monitored data is more limited. Only one of the five organizations has regular discussions of energy use between the Property Manager and the Energy Manager. None of the organizations report energy use on a level that is more detailed than total energy use for heating and total electricity use for building operation. Domestic tap water is also measured as a total; if domestic hot water is measured separately, it is also reported separately.

Investigation of indoor environmental quality in the use phase is very limited at the studied organizations. All four of the larger organizations regularly use customer satisfaction surveys, but only one of them includes any questions about indoor environment (mainly thermal comfort). Apart from that, user dissatisfaction with the indoor environment is identified only through the regular procedure for handling complaints. 
Possibilities or problems identified in this section include:

- Sustainability objectives are absent in maintenance plans.

- Too modest overarching sustainability targets, if any at all.

- Lack of detailed and gathered analysis about the environmental performance of the buildings.

- Customer satisfaction surveys are regularly conducted; however questions about indoor environmental quality are usually absent, but could be integrated into these surveys.

\subsection{Renovation Process in General}

Most organizations lack a model for managing sustainable aspects in renovation projects. Only one out of the six studied organizations states that they have a general model for managing sustainability aspects, referred to as "environmental description", which is adjusted to fit each specific renovation project. In addition, another organization said that they used the Swedish environmental rating tool Miljöbyggnad [23] as a steering tool. Among the respondents, it is rare to establish environmental programs and plans; this is done only for extensive redevelopment projects. The interviews instead revealed that how these aspects are addressed depends largely on the dedication and skill of each project manager. The interviews also showed that the project managers are provided very limited internal support about how and when to address certain sustainability aspects throughout a renovation project, and they do not always know what to ask for.

There is no consistent view among the participating organizations regarding Individual Metering and Billing (IMB) of domestic hot and cold water. One of the larger organizations fully uses IMB for all renovation projects. Two organizations prepare for subsequent installation of IMB when renovating, and the other three organizations do not consider this issue at all.

Organizational differences between new construction and renovation projects are minor. Some of the interviewed organizations have internal project managers while others use consultants. Two organizations use "renovation coordinators", who are supposed to serve as a link between tenants and the project team and handle questions, complaints or other issues raised by tenants. A more open question was also asked about how to promote better management of sustainability aspects throughout a renovation project, resulting in the following suggestions. Disseminate knowledge about sustainability aspects to stakeholders such as project managers, consultants, contractors and tenants. Involve environmental expertise to support the project manager with knowledge. Set up sustainability aspects as a recurrent point on the agenda at design team and construction site meetings and introduce checklists to help the project manager address these aspects. Start using existing environmental rating tools like Miljöbyggnad [23] as a steering tool for controlling or for setting relevant objectives. Analyze behavior of tenants since it affects energy demand and indoor environment.

Possibilities or problems identified in this section include:

- Limited routines and processes for managing sustainability aspects in projects.

- Limited use of environmental programs and plans.

- "Renovation coordinators" could probably be used more often.

- Lack of knowledge about sustainability aspects among project managers and other stakeholders.

- Project managers get insufficient support by environmental expertise. 


\subsection{Building Inspection Stage}

For property owners with large building stocks, prioritizing the building to start renovating seems to be a difficult task. This is because there is often a great need for measures at most buildings, but all of them cannot be renovated at the same time. Five out of the six studied organizations said that they prioritize by status of the construction and technical supply systems and might subsequently consider various aspects such as security and the opinions of tenants. The sixth organization prioritizes by age of the building. One difference between the different categories of organizations was that only the two smaller ones, both of which operate in a non-growth market, said that they considered the opinions of tenants.

Before launching a renovation project, most of the respondents stated that they performed a building inspection unless they believed that they already had the necessary knowledge about the building. However, this inspection is commonly performed on a general level and does not include thorough analysis of energy use, potential energy-saving measures, or evaluation of indoor environmental aspects, such as thermal comfort, moisture, noise and daylight.

At the participating organizations, alternative measures (e.g., replacing $v s$. renovating windows) are usually evaluated by means of an LCC approach and by experiences of previous projects. However, we were also interested in the views of the respondents regarding environmental performance on a life cycle basis. None of the interviewed organizations are currently considering embodied greenhouse gas emissions due to added materials when renovating. Five of the organizations showed interest in starting to perform these kinds of calculations if there were a simple and accessible tool for the purpose.

Considering resident opinions about an upcoming renovation project or having a resident involvement process is an issue that may affect the outcome, as well as resident satisfaction, of the project. The four larger organizations have some kind of tenant involvement process in which the Swedish Union of Tenants also plays a major role. Three of the organizations stated that they have joint meetings with the tenants. The meetings are mainly for sharing information about upcoming renovation projects, but tenants are encouraged to express their opinions and are somewhat able to influence decision-making. As mentioned earlier, a few organizations involve a "renovation coordinator" to facilitate communication between the project team and the tenants throughout the process. None of the participating organizations perform any kind of survey among tenants prior to a renovation project to identify for example indoor environmental problems that might be rectified during a renovation project.

Regarding occupants in housing cooperative the process of involvement is quite different. The interviews revealed that residents have to be informed much earlier in the process and more frequently. This is in line with the findings of Hauge et al., 2012 [24], who also discuss the problem of residents living in the apartments to be renovated. Our interviews showed that all property owners prefer to renovate when tenants have been evacuated, but this is not always possible due to high costs. If tenants are not evacuated, the measures to be performed may be affected.

Possibilities or problems identified in this section include:

- Limited routines on how to prioritize between buildings with renovation need.

- Inadequate investigation of buildings prior to a renovation project. 
- Embodied greenhouse gas emissions are disregarded, but the interviewees display some interest in this topic.

- Limited involvement of residents and processes for identifying and handling opinions of the residents on renovation proposals.

\subsection{Construction Stage}

Two factors that, according to the interviews, greatly affect the level of incorporation of sustainability aspects in the renovation process are the type of contract and the skill and commitment of the project manager.

Turnkey contracts are most commonly used among the interviewed organizations. Turnkey contracts are often defined as if a single contractor, procured by a client, acquires and sets up all necessary premises, equipment, supplies and operating personnel to bring the project to an operational stage. All that the client needs to do is "turn the key" to begin full and effective usage of the new (in this case renovated) facility [25]. Several of the participating organizations have also tried partnering contracts, but only two organizations use them regularly. There is no one strict definition of partnering contracts. Partnering is a project management approach to enhance performance through mutual commitment, open communication and sharing of both risks and rewards [26]. There is an overall agreement among the respondents that if the parties to a partnering contract are committed, this will yield a better project outcome. However, the main reason for using turnkey contracts is that fewer personnel are needed from the property owner's point of view. Interviews also revealed that the contractor has greater influence over the project, including sustainability aspects, with a turnkey contract than a partnering contract. This means that the outcome of the project will greatly depend on the skill and commitment of the contractor's project manager unless the procurement documents deal with sustainability aspects in a professional manner. The interviews showed that procurement documents are often standard templates that do not include sustainability aspects to a satisfactory degree. Sometimes templates for new construction were used for renovation projects, which mean that important actions at early stages may be neglected. It is often time-consuming and associated with higher costs to make changes in the construction phase.

Four out of the six participating organizations use internal project managers, and one of them has project managers who specialize in either new construction or renovation projects. The other two organizations, one small and one large, use only consultants as project managers. However, they try to use the same consultant to preserve experience to future projects. The skill and commitment of the project manager may differ according to whether internal or external project managers are assigned to the project or whether they specialize in renovation projects or not. The ability of a project manager to address sustainability issues may also differ depending on the size of the organization. Smaller organizations do not usually have the same level of in-house environmental expertise.

Possibilities or problems identified in this section include:

- Type of contract has an impact on how sustainability aspects are handled.

- Limited routines and processes for procurement of renovation projects.

- Project managers have a key role and their skill and engagement will affect how certain aspects are handled. 


\subsection{Follow-Up Stage}

After the completion of a renovation project, there should be a period of follow-up in order to verify the outcome of the performed measures before proceeding to the regular property management process. However, the interviews showed that the participating organizations perform very limited follow-up even though most respondents expressed the importance of having satisfied residents. In general, energy use is the only parameter that is monitored, i.e., monthly reading of operational energy use; indoor environmental aspects are not followed up on. Two of the organizations said that they installed temperature sensors (measuring air temperature) in a representative sample of apartments at each building, but no other aspects were considered. Indoor environmental quality is more than just temperature alone and can be defined by air temperature, operative temperature, air velocity, humidity, light and sound. Studies of satisfaction with thermal comfort have shown a discrepancy between resident opinions about comfort level and measured indoor air temperature [27].

The interviews revealed that the participating organizations perform a thorough investigation of specific parameters only if something seems to go wrong, for example much higher energy use than expected or widespread complaints from residents. None of the participating organizations use surveys or any other inspection or measurement to follow up on indoor environmental aspects.

All interviewees answered that they tried to preserve and propagate experiences among members of the project team during and after completion of a project. However, this mainly regards employees of the property owner rather than consultants or contractors, with a few exceptions.

Possibilities or problems identified in this section include:

- Limited analysis of energy use subsequent to a renovation project.

- Limited follow-up of indoor environmental quality aspects.

- No use of surveys to follow-up satisfaction among residents.

\section{Concluding Discussion}

The interviews revealed that large organizations and the housing cooperatives usually have maintenance plans, but they do not include sustainability targets. Small organizations do not have overarching sustainability targets at all; on the other hand, the person in charge at these organizations has good tacit knowledge about the status of the building stock. This, at least for very small organizations like the ones in this study, compensates the lack of maintenance plans. It should also be noted that the small organizations interviewed in this study operate in a small local market, which also seems to have a positive influence on the tenant involvement process.

Overarching sustainability objectives within an organization might possibly support formulation of sustainability requirements for renovation projects. Monitoring and following up on the use of energy and domestic tap water in the management process is also an important starting point for formulating adequate sustainability targets and selecting measures as part of a renovation process. When it comes to overarching sustainability targets, the smaller organizations and housing cooperatives do not have such targets. They are more common in the larger organizations. However, these overarching targets tend to be too modest. One example is targets based on the 2020 objective (i.e., $20 \%$ reduction of operational energy demand by 2020) since this implies that the ambition of $50 \%$ reduction of 
operational energy demand by 2050 will most likely not be met due to lock-in effects-i.e., measures such as replacement of windows, renovation of facades and replacement of plumbing equipment are normally performed at intervals of 30-50 years.

The interviews revealed that large organizations use customer satisfaction surveys regularly, which rarely, if ever, include questions about indoor environmental quality. Doing so could be an effective way to garner resident opinions about this matter and identify areas for improvement. Small organizations do not conduct such surveys. However, as previously mentioned, small organizations seem to have closer and more continuous contact with tenants, which makes up for the lack of such surveys. None of the interviewed organizations performed any kind of special survey among tenants prior to a renovation project. The process of tenants' involvement may take many different forms, including questionnaires, interviews and group meetings. The aim should be to investigate what values to preserve and what the important areas for improvement are from the point of view of tenants. According to Suschek-Berger and Ornetzeder (2010) [11], early and systematic involvement of tenants could increase support for extensive renovation measures.

Regardless of the type and size of the organization, it is unusual to set up environmental plans; this occurs only as part of extensive redevelopment projects performed by large organizations. An environmental plan is the document in which a property owner sums up the targets for energy, environment, indoor environmental quality and the like. This is an important document for procurement and affects the aspects that will be addressed throughout a project, as well as the outcome. However, property owners and their project managers need to have more support from experts already from early stages to be able to address sustainability aspects in the right way. This could be done by creating better templates or checklists so that project managers know what to ask for in different project stages.

Regarding monitoring of energy use, there are no differences between organizations. Most of them summarize energy use on a level of total heating and building electricity. Analyzing energy usage is rare in all cases. Analysis of energy use is somewhat better among housing cooperatives because many of them buy the service from their facility management provider. Compilation and analysis of energy use is clearly important for selecting the right measures and for future evaluation of measures that have been performed. Such an analysis is not usually a time-consuming effort. The problem is that project managers do not know how and when to get it done. Internal support such as checklists and illustrative examples might be helpful. Building inspections are performed prior to a renovation project by most of the interviewed organizations. However, the inspections are often on a general level without an in-depth analysis of for example energy use or indoor environmental problems regardless of the size and type of the organization. Performing a proper building inspection early in the process may be important for understanding the measures to take during the upcoming renovation project.

The type of contract that is used when renovating does not differ very much between organizations, and turnkey contracts are by far the most common. The type of contract to use is an issue for debate and there are many proponents of partnering contracts, which mean that partnering can support mutual efforts that generate higher performance of building projects [28,29]. The skill and commitment of the project manager is the key to ensuring that sustainability aspects are addressed in the right way. The interviews revealed that project managers receive little support in this matter. The interviews also showed that checklists and templates for new construction are sometimes used for renovation projects. This 
may lead to neglecting parts of the existing building that set preconditions for the forthcoming renovation project. This is also an expression of the tendency for new construction to attract more attention and to be considered more exciting to work on than renovation, as discussed by Ástmarsson et al., 2013 [30].

During the analysis of the interviews, recurring topics and themes occurred which we have condensed into Table 2. The table summarizes key considerations or barriers that were identified during the reported interview study and that were seen as important to deal with better in order to promote more sustainable renovation processes among residential property owners. The considerations and barriers listed in Table 2 will be the starting points for the development of a process model for systematizing integration and effectively addressing energy, environmental, and indoor environmental quality aspects throughout a renovation process. The process model will also be applicable to other types of buildings even though our focus is on residential buildings and, more specifically, rental apartment buildings.

Table 2. Summary of key considerations or barriers identified during the interview study to be able to handle increasing the sustainability outcomes of renovation processes.

\begin{tabular}{|c|c|}
\hline Area of concern & Key considerations/barriers \\
\hline \multirow{4}{*}{$\begin{array}{l}\text { Routines \& } \\
\text { processes }\end{array}$} & $\begin{array}{l}\text { Lack of procedures, checklists etc. for managing sustainability aspects throughout } \\
\text { a renovation project from early inspections to procurement of contractors and all } \\
\text { the way to follow-up. }\end{array}$ \\
\hline & Limited use of environmental programs and plans. \\
\hline & $\begin{array}{l}\text { Lack of energy, environmental or sustainability objectives in maintenance plans } \\
\text { and overly modest ambitions for overarching sustainability targets. }\end{array}$ \\
\hline & Limited tenant involvement process. \\
\hline \multirow{3}{*}{$\begin{array}{l}\text { Competence of } \\
\text { personnel }\end{array}$} & $\begin{array}{l}\text { Limited engagement or skill of project managers may greatly affect how } \\
\text { sustainability aspects are addressed during a project. }\end{array}$ \\
\hline & $\begin{array}{l}\text { Lack of support for project managers concerning the sustainability aspects to } \\
\text { address and the actions to advocate. }\end{array}$ \\
\hline & $\begin{array}{l}\text { Lack of environmental expertise to support the project team or manager throughout } \\
\text { the renovation process. }\end{array}$ \\
\hline \multirow{3}{*}{$\begin{array}{l}\text { Environmental } \\
\text { performance and } \\
\text { energy use }\end{array}$} & Only limited inspection and evaluation of indoor environmental aspects. \\
\hline & Lack of detailed analysis of energy performance in early stages. \\
\hline & Overly general follow-up of both environmental improvements and energy use. \\
\hline \multirow{3}{*}{$\begin{array}{l}\text { Evaluation of } \\
\text { measures }\end{array}$} & $\begin{array}{l}\text { Large differences (even in the same organization) when evaluating the economic } \\
\text { and technical aspects of renovation measures. }\end{array}$ \\
\hline & $\begin{array}{l}\text { Lack of overarching guidelines for input data, such as annual increases in energy } \\
\text { prices, useful life of products, inflation etc. }\end{array}$ \\
\hline & $\begin{array}{l}\text { No consideration of embodied greenhouse gas emissions due to added materials in } \\
\text { renovation projects. }\end{array}$ \\
\hline \multirow{2}{*}{$\begin{array}{l}\text { Customer } \\
\text { satisfaction } \\
\text { surveys }\end{array}$} & $\begin{array}{l}\text { Surveys are regularly conducted but seldom include questions about indoor } \\
\text { environmental quality. }\end{array}$ \\
\hline & $\begin{array}{l}\text { No in-depth questionnaires to identify problems with the indoor environment prior } \\
\text { to a renovation project. }\end{array}$ \\
\hline
\end{tabular}


Based on the presented in-depth interview study, studies of organizational process documents and literature, a generic gross process model is developed. The aim of the model is to support clients, project managers and other involved stakeholders and to promote better management of sustainability aspects throughout a renovation project. Key considerations and barriers listed in Table 2 are addressed by the model; however, it should also emphasize positive examples found through the interviews. In the model, early stages and follow-up are focused on since they are the stages that differ most from the process of new construction. Incorporating management of sustainability aspects as early in the process as possible is also vital to success. Key starting points for development of the process model include:

- The layout of the model should allow organizations that do not have a regular renovation process description to use it with slight modifications. If a property owner already has a renovation process description, the model ought to serve as inspiration for incorporating significant elements that are not currently included.

- Provide suggestions for routines that minimize the risk of not considering sustainability aspects due to limited skills and interest by the project manager and/or contractor.

- Provide applied checklists, links to existing adequate and qualitative checklists and tools for e.g., early inspections, environmental target formulation, and environmental plans for hands-on application.

- Provide suggestions for formulations and performance levels of key sustainability targets for renovation projects to encourage targets that promote national EQOs, EU regulations and international commitments.

The process model will be structured around actual project stages. Each stage will consist of short informative and motivating text taking up relevant activities (in relation to supporting and promoting high sustainability outcomes of the renovation process) in the addressed project stage. By providing practical tools and examples on how to perform addressed activities, the basic idea is to encourage and inspire property owners to systematically manage sustainability aspects in their practical decisions and actions. The present version of the process model is being further developed in an iterative process together with the participating organizations. Different stages of the model will be tested as part of case studies among the participating organizations and will be implemented as examples in appendices.

A significant component in the process model is to cover relevant and challenging sustainability targets for the renovation project. This issue has not been dealt with very much in previous works. In this ongoing project, we will suggest sustainability targets with the starting point of planetary boundaries [31]. However, this is not presented in this paper.

Sustainable renovation is a notion that is being used more and more by the building industry and academia. However, the interpretation of the notion is too a high degree varying. Even though a majority of research and development projects in this field focus on energy-saving measures, a number of authors have also tried to elaborate more on the definition of sustainable renovation as a concept [32]. Thuvander et al., 2012 [12] reason about various terms for building changes, including renovation, refurbishment, retrofitting and restoration. They refer to the notion of sustainable renovation as the ambition to fulfill the dimensions of environmental, social and economic sustainability when making changes to buildings. Högberg et al., 2014 [33] discuss aspects of relevance for sustainable renovation as a notion in relation to environmental, social, economic and technical sustainability. 
Mjörnell et al., 2014 [34] develop a tool for identifying an optimal set of renovation measures based on a number of sustainability criteria, including Life Cycle Assessment (LCA) for environmental aspects, LCC for economic aspects, and a set of indicators for social aspects. The latter mainly regards aspects of the neighborhood and processes such as tenant involvement. A similar approach is the European Retrofit Advisor, which also aims for a multi-criteria assessment with regard to the sustainability of various renovation scenarios [35]. In addition, voluntary certification tools and standards (e.g., BREEAM, LEED, Miljöbyggnad in Sweden, and the CEN TC350 series) are currently becoming more and more popular interpretations or practical definitions of the notion of sustainable renovation, sustainable buildings and similar concepts. These tools both point out sustainability aspects to deal with and define qualifying criteria levels for these aspects. Therefore, such criteria could also be used when setting sustainability targets for renovation projects [36].

It is far from obvious that property owners will perform sustainable renovation projects even if they have the knowledge and tools to do so. Financial, not technical, aspects constitute the barrier. Almost every organization operates according to the profit motive, which means that there is a huge gap between what needs to be done and what is being done under present conditions. This is also shown in the interview study. We would argue that enabling more sustainable renovation projects requires financial subsidies or other incentives from society. There is also a need for new business models that value environmental and social aspects higher.

\section{Acknowledgments}

The work presented in this paper is the result of the first part of a Swedish research and development project called Environmental Management of Renovation Processes and funded by the Swedish Research Council (Formas), the six interviewed property owners and four consulting companies. We would like to thank all organizations involved as well as the ten interviewees. We are also grateful to Professor Göran Finnveden for his valuable comments on this paper. The authors are further grateful to the contributions of two anonymous reviews, both of whose comments motivated improvements to this work.

\section{Author Contributions}

All three authors contributed equally to the design of the interviews. Stefan Olsson conducted the interviews, analyzed the data and contributed to drafting the paper. Tove Malmqvist contributed to the concept and design of the paper. Mauritz Glaumann contributed useful advice and modified the draft. Stefan Olsson was in charge of the final version of the paper.

\section{Conflicts of Interest}

The authors declare no conflict of interest. 


\section{References}

1. Economidou, M.; Atanasiu, B.; Despret, C.; Maio, J.; Nolte, I.; Rapf, O.; Laustsen, J.; Ruyssevelt, P.; Staniaszek, D.; Strong, D.; et al. Europe's Buildings under the Microscope A Country-by-Country Review of the Energy Performance of Buildings; Buildings Performance Institute Europe (BPIE): Brussel, Belgium, 2011.

2. European Commission. Communication from the Commission to the European Parliament, the Council, the European Economic and Social Committee and the Committee of the Regions-A Roadmap for Moving to a Competitive Low Carbon Economy in 2050; European Commission: Brussels, Belgium, 2011.

3. European Union. Directive 2012/27/EU of the European Parliament and of the Council of 25 October 2012 on the energy performance of buildings. Off. J. Eur. Union 2012, L315, 1-10.

4. Swedish Environmental Protection Agency. Miljömålen-Årlig uppföljning av Sveriges miljökvalitetsmål och etappmål 2014 (Environmental Objectives-Annual Follow-Up of Sweden's Environmental Quality Objectives and Milestones 2014); Naturvårdsverket: Stockholm, Sweden, 2014; pp. 25-236. (In Swedish)

5. Swedish Government. Regeringens Proposition 1997/98:145-Svenska Miljömål. Miljöpolitik för ett hållbart Sverige (Government bill 1997/98:145-Swedish Environmental Objectives. Environmental Policy for a Sustainable Sweden); Regeringens Proposition: Stockholm, Sweden, 1998. (In Swedish)

6. Swedish Government. Regeringens Proposition 2005/06:145-Nationellt Program för Energieffektivisering och Energismart Byggande (Government bill 2005/06:145-National Program for Energy Efficiency and Energy-Smart Construction); Regeringens Proposition: Stockholm, Sweden, 2005. (In Swedish)

7. Swedish Government. Regeringens Proposition 2008/09:162-En sammanhållen klimat-och energipolitik (Governmnet bill 2008/09:162 - A cohesive climate and energy policy); Regeringens Proposition: Stockholm, Sweden, 2008. (In Swedish)

8. Swedish Government. Preciseringar av miljökvalitetsmålen och en första uppsättning etappmål (Specification of the Environmental Quality Objectives and a First Set of Milestones); Ministry of Environment: Stockholm, Sweden, 2012. (In Swedish)

9. Statistics Sweden. Available online: http://www.statistikdatabasen.scb.se/pxweb/sv/ssd/START BO_BO0104/BostadsbestandK/?rxid=4bd5e954-a4f2-46ba-9763-14c5806e12c9 (accessed on 1 February 2014).

10. Hall, T.; Vidén, S. The Million Homes Programme: A review of the great Swedish planning project. Plan. Perspect. 2006, 20, 301-328.

11. Suschek-Berger, J.; Ornetzeder, M. Inclusion of Occupants and other Stakeholders in Sustainable Refurbishment Processes in Multi-Floor Residential Buildings. Open House Int. 2010, 35, 33-38.

12. Thuvander, L.; Femenías, P.; Mjörnell, K.; Meiling, P. Unveiling the Process of Sustainable Renovation. Sustainability 2012, 4, 1188-1213.

13. Power, A. Does demolition or refurbishment of old and inefficient homes help to increase our environmental, social and economic viability? Energy Policy 2008, 36, 4487-4501. 
14. Jonsson, D.K.; Gustafsson, S.; Wangel, J.; Höjer, M.; Lundqvist, P.; Svane, Ö. Energy at your service: Highlighting energy usage systems in the context of energy efficiency analysis. Energy Effic. 2011, 4, 355-369.

15. Svane, Ö. Basic starting points for environmental management in the housing sector. In Housing: Socioeconomic, Availability, and Development Issues; Hammond, E.P., Noyes, A.D., Eds.; Nova Science Publishers, Inc.: New York, NY, USA, 2008; Volume 1, pp. 149-160.

16. Svenfelt, Å.; Engström, R.; Svane, Ö. Decreasing energy use in buildings by $50 \%$ by $2050-\mathrm{A}$ backcasting study using stakeholder groups. Technol. Forecast. Soc. Chang. 2010, 78, 785-796.

17. Liu, L.; Thoresson, J. Exploring indoor climate and comfort effects in refurbished multi-family dwellings with improved energy performance. Smart Innov. Syst. Technol. 2013, 22, 463-478.

18. Cattano, C.; Valdes-Vasquez, R.; Plumblee, J.M.; Klotz, L. Potential Solutions to Common Barriers Experienced during the Delivery of Building Renovations for Improved Energy Performance: Literature Review and Case Study. J. Archit. Eng. 2013, 19, 164-167.

19. Häkkinen, T.; Belloni, K. Barriers and drivers for sustainable building. Build. Res. Inf. 2011, 39, 239-255.

20. Kvale, S.; Brinkmann, S. INTERVIEWS Learning the Craft of Qualitative Research Interviewing, 2nd ed.; SAGE Publications Inc.: Thousand Oaks, CA, USA, 2009; pp. 99-104.

21. Gregow, T. Swedish Law. In Sveriges Rikes Lag, Jordabalk (1970:994); Norstedts Juridik: Stockholm, Sweden, 2006. (In Swedish)

22. Swedish rent tribunal. Available online: http://www.hyresnamnden.se/Amnesomraden/Skalig-hyra/ Bruksvarde/ (accessed on 14 March 2014).

23. Malmqvist, T.; Glaumann, M.; Svenfelt, Å.; Carlsson, P.-O.; Erlandsson, M.; Andersson, J.; Wintzell, H.; Finnveden, G.; Lindholm, T.; Malmström, T.-G. A Swedish environmental rating tool for buildings. Energy 2011, 36, 1893-1899.

24. Hauge, A.L.; Thomsen, J.; Löfström, E. How to get residents/owners in housing cooperatives to agree on sustainable renovation. Energy Effic. 2012, 6, 315-328.

25. Merna, A.; Smith, N.J. Project managers and the use of turnkey contracts. Int. J. Proj. Manag. 1990, 8, 183-189.

26. Eriksson, P.E. Partnering: What is it, when should it be used, and how should it be implemented? Constr. Manag. Econ. 2010, 28, 905-917.

27. Isaksson, C.; Karlsson, F. Indoor climate in low-energy houses-An interdisciplinary investigation. Build. Environ. 2006, 41, 1978-1690.

28. Kadefors, A. Trust in project relationships-Inside the black box. Int. J. Proj. Manag. 2004, 22, $175-182$.

29. Eriksson, P.E.; Westberg, M. Effect of cooperative procurement procedures on construction project performance: A conceptual framework. Int. J. Proj. Manag. 2011, 29, 197-208.

30. Ástmarsson, B.; Jensen, P.A.; Maslesa, E. Sustainable renovation of residential buildings and the landlord/tenant dilemma. Energy Policy 2013, 63, 355-362.

31. Steffen, W.; Richardson, K.; Rockström, J.; Cornell, S.E.; Fetzer, I.; Bennett, E.M.; Biggs, R.; Carpenter, S.R.; de Vries, W.; de Wit, C.A.; et al. Planetary boundaries: Guiding human development on a changing planet. Science 2015, doi:10.1126/science.1259855. 
32. Olsson, S.; Liljenström, C.; Malmqvist, T. Miljöstyrning av Renoveringsprocessen: Intervjustudie Samt Litteratur-Och Projektsammanställning; KTH Royal Institute of Technology: Stockholm, Sweden, 2014; pp. 20-62. (In Swedish)

33. Högberg, L. Building Sustainability-Studies on incentives in construction and management of real estate. Ph.D. Thesis, KTH Royal Institute of Technology, Stockholm, Sweden, December, 2014.

34. Mjörnell, K.; Boss, A.; Lindahl, M.; Molnar, S. A Tool to Evaluate Different Renovation Alternatives with Regard to Sustainability. Sustainability 2014, 6, 4227-4245.

35. E2ReBuild. Available online: http://www.e2rebuild.eu/en/events/workplan/pd/retrofitadvisor/Sidor/ default.aspx (accessed on 4 June 2014).

36. Brown, N.W.O.; Malmqvist, T.; Bai, W.; Molinari, M. Sustainability assessment of renovation packages for increased energy efficiency for multi-family buildings in Sweden. Build. Environ. 2013, 61, 140-148.

(C) 2015 by the authors; licensee MDPI, Basel, Switzerland. This article is an open access article distributed under the terms and conditions of the Creative Commons Attribution license (http://creativecommons.org/licenses/by/4.0/). 